\title{
Variable stocking version of Plonski's yield tables formulated
}

\author{
by Bijan Payandeh and Yonghe Wang
}

Plonski's yield tables have been used extensively in forest management, economic evaluation, and as a basis for management planning in Ontario. However, because these tables are based on site classes, they are not directly applicable to uneven-aged mixedwood cover types. A four-parameter nonlinear model was employed to express various stand attributes as a function of stand age and recently developed basal area indices for the major species in Ontario. The resulting variable stocking yield functions will be applicable to even-aged stands as well as the boreal mixedwood. Basal area index proved superior to site index for estimating both merchantable basal area and volume for the James River/Marathon data set representing boreal mixed from Northcentral Ontario. In addition, stand basal area index may be determined easily and inexpensively via horizontal point sampling or prism cruising.

Key word: Basal area index, sigmoidal growth curve, variable stocking

\section{Introduction}

Plonski $(1956,1960,1974)$ constructed normal yield tables for the following major forest types in Ontario: black spruce (Picea mariana [Mill.] B.S.P.), jack pine (Pinus banksiana Lamb.), aspen (Populus tremuloides Michx.), white birch (Betula papyrifera Marsh.), red pine (Pinus resinosa Ait.), white pine (Pinus strobus L.), and tolerant hardwoods. Plonski (1956) gave a detailed account of the construction and indicated use of his tables.

Normal yield tables have been used extensively in forest management and economic evaluation research and as a basis for management planning inventory. This is particularly true of Plonski's yield tables in Ontario. However, these tables were constructed on the basis of balanced and harmonized curves, i.e., no mathematical equations were given for them. Thus, to utilize the tables, it is necessary to look up or interpolate values for given variables individually from the appropriate tables or graphs. Payandeh $(1973,1991)$ formulated Plonski's yield tables by expressing various stand attributes as function of stand age and site index.

Despite its possible shortcomings (Griegal 1984; Monserud 1984a) site index has been the most widely used means of estimating potential forest site productivity in North America. However, it is unsatisfactory for use in uneven-aged mixedwood cover types. This is mainly due to the difficulty in

Canadian Forest Service - Ontario, 1219 Queen Street East, Sault Ste. Marie, Ontario, Canada P6A 5M7.
Les tables de rendement de Plonski ont été utilisées fréquemment en aménagement forestier, en évaluation forestière et en tant que base de planification de l'aménagement en Ontario. Toutefois, parce que ces tables reposent sur les classes de station, elles ne sont pas directement applicables dans le cas de peuplements inéquiennes mélangés. Un modèle non linéaire à quatre variables a été utilisé pour exprimer les différents paramètres du peuplement en tant que fonction de l'âge du peuplement et des indices de surface terrière élaborés récemment pour les principales espèces de l'Ontario. Les fonctions de densité relative variable obtenues seront applicables tant pour les peuplements équiennes que pour les peuplements mélangés nordiques. L'indice de superficie terrière s'est avéré supérieur à l'indice de station dans le cas d'estimation de la surface terrière et du volume marchand dans le cas des données de la compagnie James River/Marathon représentant les peuplements mélangés nordiques du centrenord de l'Ontario. De plus, l'indice de la surface terrière du peuplement pourrait être déterminé facilement et à peu de frais au moyen d'un échantillonnage par points horizontaux ou un sondage au prisme.

Mots clés: indice de la surface terrière, courbe de croissance sigmoïde, densité relative variable finding trees whose height development clearly represents the site's potential and an accurate stand age determination.

Since areas of good site quality generally have high rates of height and/or basal area growth, volume production potential and basal area growth should be highly and positively correlated (Ffolliott and Worley 1973; Johnstone 1976). Therefore, a measure of site productivity based on basal area growth (i.e. basal area index) should prove useful in developing variable stocking yield tables. Such yield tables could be applicable to single species even-aged stands as well as uneven-aged mixed species (e.g. boreal mixedwood cover types).

The objective of this paper is to develop base-age specific basal area indices and a variable stocking version of Plonski's yield functions and tables. The main advantage of the revised functions is that the yield models can be applied to normal even-aged stands as well as uneven-aged mixedwood cover types. Stand total basal area can be determined easily and inexpensively via horizontal point sampling or prism cruising.

\section{Methods}

Total tree height growth over age usually shows asymptotic patterns; therefore, the most widely used site index models are sigmoidal in shape (Richards 1959; Lundgren and Dolid 1970; Ek 1971; Payandeh 1977; Monserud 1984b). Stand basal area in even-aged stands also frequently follows sigmoidal patterns (Turnbull and Pienaar 1966; Pienaar and Turnbull 1973; Yang et al. 1978). We propose the following constrained model to express total basal area growth patterns over age: 


\begin{tabular}{|c|c|c|c|c|c|}
\hline Stand attribute & $b_{1}$ & $b_{2}$ & $b_{3}$ & $\mathbf{b}_{4}$ & $\mathbf{R}^{2}$ \\
\hline \multicolumn{6}{|c|}{ Black spruce } \\
\hline Height (m) & 1.4347 & 0.8020 & 0.0203 & 1.6655 & 0.99 \\
\hline $\mathrm{DBH}(\mathrm{cm})$ & 1.9093 & 0.7171 & 0.0164 & 1.4429 & 0.99 \\
\hline No. trees ha ${ }^{-1}$ & 12815.6823 & -0.7738 & 0.0060 & -1.0751 & 0.99 \\
\hline $\mathrm{BA}\left(\mathrm{m}^{2} \mathrm{ha}^{-1}\right)$ & 10.1416 & 0.4256 & 0.0433 & & 0.99 \\
\hline $\begin{array}{l}\text { Gros. vol. }\left(\mathrm{m}^{3} \mathrm{ha}^{-1}\right) \text { of } \\
\text { main stand }\end{array}$ & 12.9626 & 0.9974 & 0.0267 & 3.3174 & 0.99 \\
\hline $\begin{array}{l}\text { Gros. vol. }\left(\mathrm{m}^{3} \mathrm{ha}^{-1}\right) \text { of } \\
\text { total production }\end{array}$ & 11.3908 & 1.1117 & 0.0234 & 3.1272 & 0.99 \\
\hline Gros. merch. vol. $\left(\mathrm{m}^{3} \mathrm{ha}^{-1}\right)$ & 1.2826 & 1.6590 & 0.0297 & 8.0576 & 0.96 \\
\hline $\begin{array}{l}\text { Merch. vol. }\left(\mathrm{m}^{3} \mathrm{ha}^{-1}\right) \\
\text { to } 7-\mathrm{cm} \text { DBH }\end{array}$ & 5.8019 & 1.2085 & 0.0322 & 5.9513 & 0.98 \\
\hline \multicolumn{6}{|c|}{ Jack pine } \\
\hline Height (m) & 0.1633 & 1.5079 & 0.0385 & 1.7461 & 0.99 \\
\hline $\mathrm{DBH}(\mathrm{cm})$ & 0.1623 & 1.5253 & 0.0327 & 1.9285 & 0.99 \\
\hline No. trees $\mathrm{ha}^{-1}$ & 3410964.7300 & -2.6330 & 0.0360 & -3.7960 & 0.99 \\
\hline $\mathrm{BA}\left(\mathrm{m}^{2} \mathrm{ha}^{-1}\right)$ & 2.8235 & 0.6944 & 0.0630 & & 0.99 \\
\hline $\begin{array}{l}\text { Gros. vol. }\left(\mathrm{m}^{3} \mathrm{ha}^{-1}\right) \text { of } \\
\text { main stand }\end{array}$ & 0.1677 & 2.2609 & 0.0434 & 2.2676 & 0.97 \\
\hline $\begin{array}{l}\text { Gros. vol. }\left(\mathrm{m}^{3} \mathrm{ha}^{-1}\right) \text { of } \\
\text { total production }\end{array}$ & 0.2520 & 2.2640 & 0.0380 & 2.6547 & 0.99 \\
\hline Gros. merch. vol. $\left(\mathrm{m}^{3} \mathrm{ha}^{-1}\right)$ & 0.0377 & 2.6819 & 0.0611 & 7.9121 & 0.97 \\
\hline Merch. vol. $\left(\mathrm{m}^{3} \mathrm{ha}^{-1}\right)$ & 0.0579 & 2.5602 & 0.0668 & 7.7797 & 0.96 \\
\hline to $7-\mathrm{cm} \mathrm{DBH}$ & & & & & \\
\hline \multicolumn{6}{|c|}{ Aspen } \\
\hline Height (m) & 0.1010 & $1.6809^{\circ}$ & 0.0331 & 1.5163 & 0.99 \\
\hline $\mathrm{DBH}(\mathrm{cm})$ & 0.1016 & 1.8012 & 0.0129 & 1.1814 & 0.99 \\
\hline No. trees ha ${ }^{-1}$ & 1853.1940 & -2.3830 & 0.000015 & -1.0464 & 0.99 \\
\hline $\mathrm{BA}\left(\mathrm{m}^{2} \mathrm{ha}^{-1}\right)$ & 1.9607 & 0.8651 & 0.0420 & & 0.99 \\
\hline $\begin{array}{l}\text { Gros. vol. }\left(\mathrm{m}^{3} \mathrm{ha}^{-1}\right) \text { of } \\
\text { main stand }\end{array}$ & 0.0920 & 2.5100 & 0.0421 & 3.4203 & 0.99 \\
\hline $\begin{array}{l}\text { Gros. vol. }\left(\mathrm{m}^{3} \mathrm{ha}^{-1}\right) \text { of } \\
\text { total production }\end{array}$ & 0.0518 & 2.7632 & 0.0380 & 3.4523 & 0.99 \\
\hline Gros. merch. vol. $\left(\mathrm{m}^{3} \mathrm{ha}^{-1}\right)$ & 0.0333 & 2.7662 & 0.0582 & 8.3500 & 0.98 \\
\hline Merch. vol. $\left(\mathrm{m}^{3} \mathrm{ha}^{-1}\right)$ & 0.0507 & 2.6739 & 0.0455 & 4.4042 & 0.99 \\
\hline \multicolumn{6}{|c|}{ White birch } \\
\hline Height (m) & 0.3468 & 1.3100 & 0.0503 & 2.6670 & 0.99 \\
\hline $\mathrm{DBH}(\mathrm{cm})$ & 0.0936 & 1.7505 & 0.0347 & 2.4261 & 0.99 \\
\hline No. trees ha ${ }^{-1}$ & 355005.4518 & -2.0202 & 0.0242 & -2.4167 & 0.99 \\
\hline $\mathrm{BA}\left(\mathrm{m}^{2} \mathrm{ha}^{-1}\right)$ & 1.0759 & 1.0210 & 0.0661 & & 0.99 \\
\hline $\begin{array}{l}\text { Gros. vol. }\left(\mathrm{m}^{3} \mathrm{ha}^{-1}\right) \text { of } \\
\text { main stand }\end{array}$ & 0.4803 & 1.9673 & 0.0574 & 5.0558 & 0.99 \\
\hline $\begin{array}{l}\text { Gros. vol. }\left(\mathrm{m}^{3} \mathrm{ha}^{-1}\right) \text { of } \\
\text { total production }\end{array}$ & 0.5205 & 2.0197 & 0.0520 & 4.9265 & 0.99 \\
\hline Gros. merch. vol. $\left(\mathrm{m}^{3} \mathrm{ha}^{-1}\right)$ & 0.0108 & 3.0902 & 0.0657 & 11.9262 & 0.99 \\
\hline $\begin{array}{l}\text { Merch. vol. }\left(\mathrm{m}^{3} \mathrm{ha}^{-1}\right) \\
\text { to } 7-\mathrm{cm} \text { DBH }\end{array}$ & 0.0623 & 2.5835 & 0.0697 & 12.3547 & 0.99 \\
\hline \multicolumn{6}{|c|}{ Tolerant hardwood } \\
\hline Height (m) & 1.3440 & 0.9523 & 0.0295 & 1.9139 & 0.99 \\
\hline $\mathrm{BA}\left(\mathrm{m}^{2} \mathrm{ha}^{-1}\right)$ & 0.8239 & 1.2802 & 0.0229 & & 0.95 \\
\hline $\begin{array}{l}\text { Gros. vol. }\left(\mathrm{m}^{3} \mathrm{ha}^{-1}\right) \text { of } \\
\text { main stand }\end{array}$ & 7.4984 & 1.3066 & 0.0202 & 2.3999 & 0.99 \\
\hline Gros. merch. vol. $\left(\mathrm{m}^{3} \mathrm{ha}^{-1}\right)$ & 3.5345 & 1.4627 & 0.0260 & 4.0074 & 0.99 \\
\hline \multicolumn{6}{|c|}{ White pine } \\
\hline Height (m) & 0.0987 & 1.5695 & 0.0240 & 2.2567 & 0.91 \\
\hline $\mathrm{BA}\left(\mathrm{m}^{2} \mathrm{ha}^{-1}\right)$ & 4.5074 & 0.6090 & 0.0671 & & 0.91 \\
\hline $\begin{array}{l}\text { Gros. vol. }\left(\mathrm{m}^{3} \mathrm{ha}^{-1}\right) \text { of } \\
\text { main stand }\end{array}$ & 0.4448 & 1.9504 & 0.0242 & 2.4693 & 0.90 \\
\hline Gros. merch. vol. $\left(\mathrm{m}^{3} \mathrm{ha}^{-1}\right)$ & 0.0899 & 2.3574 & 0.0293 & 4.3459 & 0.90 \\
\hline \multicolumn{6}{|c|}{ Red pine } \\
\hline Height (m) & 0.0244 & 1.8961 & 0.0274 & 1.3360 & 0.97 \\
\hline $\mathrm{BA}\left(\mathrm{m}^{2} \mathrm{ha}^{-1}\right)$ & 8.6021 & 0.4461 & 0.0548 & & 0.99 \\
\hline $\begin{array}{l}\text { Gros. vol. }\left(\mathrm{m}^{3} \mathrm{ha}^{-1}\right) \text { of } \\
\text { main stand }\end{array}$ & 0.1182 & 2.2674 & 0.0341 & 2.2919 & 0.96 \\
\hline Gros. merch. vol. $\left(\mathrm{m}^{3} \mathrm{ha}^{-1}\right)$ & 0.0091 & 2.9333 & 0.0381 & 3.5955 & 0.96 \\
\hline
\end{tabular}




\begin{tabular}{|c|c|c|c|c|c|c|c|c|}
\hline \multirow[b]{2}{*}{ Age } & \multirow[b]{2}{*}{$\begin{array}{l}\text { DBH } \\
(\mathrm{cm})\end{array}$} & \multirow[b]{2}{*}{$\begin{array}{l}\text { Height } \\
\text { (m) }\end{array}$} & \multirow[b]{2}{*}{ Tree $h^{-1}$} & \multirow[b]{2}{*}{$\begin{array}{c}\text { Basal } \\
\text { area }\left(\mathrm{m}^{2} \mathrm{ha}^{-1}\right)\end{array}$} & \multicolumn{2}{|c|}{ Gross total volume $\left(\mathrm{m}^{3} \mathrm{ha}^{-1}\right)$} & \multicolumn{2}{|c|}{ Volume $\left(\mathrm{m}^{3} \mathrm{ha}^{-1}\right)$} \\
\hline & & & & & $\begin{array}{c}\text { Main } \\
\text { stand }\end{array}$ & $\begin{array}{c}\text { Total } \\
\text { production }\end{array}$ & $\begin{array}{l}\text { Gross } \\
\text { merch. }\end{array}$ & $\begin{array}{c}\text { To } 7 \mathrm{~cm} \\
\text { DOB }\end{array}$ \\
\hline 20 & 2.5 & 2.6 & 13143.5 & 2.5 & 13.8 & 14.7 & 0.3 & 2.6 \\
\hline 30 & 4.3 & 4.2 & 8771.1 & 7.6 & 35.6 & 37.4 & 2.6 & 12.5 \\
\hline 40 & 6.0 & 5.7 & 6641.2 & 14.0 & 63.6 & 67.1 & 9.9 & 31.8 \\
\hline 50 & 7.5 & 7.1 & 5388.1 & 20.0 & 93.4 & 99.6 & 23.3 & 57.5 \\
\hline 60 & 8.8 & 8.3 & 4566.1 & 24.9 & 121.9 & 131.9 & 41.8 & 85.4 \\
\hline 70 & 10.0 & 9.4 & 3987.3 & 28.5 & 147.5 & 161.9 & 63.0 & 112.0 \\
\hline 80 & 11.0 & 10.4 & 3558.7 & 31.1 & 169.5 & 188.8 & 84.2 & 135.3 \\
\hline 90 & 11.8 & 11.3 & 3229.3 & 32.8 & 187.8 & 212.1 & 103.8 & 154.6 \\
\hline 100 & 12.5 & 12.0 & 2969.0 & 34.0 & 202.7 & 231.9 & 120.8 & 170.0 \\
\hline 110 & 13.1 & 12.6 & 2758.4 & 34.8 & 214.7 & 248.4 & 135.0 & 181.9 \\
\hline 120 & 13.6 & 13.2 & 2584.8 & 35.3 & 224.2 & 262.1 & 146.5 & 191.0 \\
\hline
\end{tabular}

\begin{tabular}{lccccccrr}
\hline \multicolumn{2}{l}{ Table 3. Black spruce variable stocking yield table for a basal area index of $\mathbf{3 0} \mathbf{~ m}^{\mathbf{2}}$} \\
\hline
\end{tabular}

$$
\begin{aligned}
G_{t} & =b_{1} B I^{b_{2}}\left(1-e^{-b_{3} t}\right)^{p} \text { with } \\
p & =\frac{\ln \left(\frac{\mathrm{BI}}{\mathrm{b}_{1} B I^{b_{2}}}\right)}{\ln \left(1-e^{-b_{3} t_{1}}\right)}
\end{aligned}
$$

where $G_{\mathrm{t}}$ is stand total basal area $\left(\mathrm{m}^{2}\right)$ at age $t ; B I$ is basal area index or total basal area at a given base age, e.g., 50, years; $t$ is stand age in years; $t_{\mathrm{i}}$ is index age or 50 years; and $b_{\mathrm{i}} \mathrm{s}$ are model parameters to be estimated.

Note that the above model is conditioned such that $G_{\mathrm{t}}=B I$ when $t=50$ (i.e., $p$ is calculated so that equation (1) satisfies this condition).

For each species, values for various characteristics of interest, such as stand age, height, basal area, DBH, number of trees, gross total volume, etc., were read directly from the appropriate tables in Plonski (1974). The following four parameter nonlinear model was used to express various stand attributes as a function of stand age and basal area index:

$$
Y=b_{1} B I^{b_{2}}\left(1-e^{-b_{3} t}\right)^{b_{4}}
$$

where $Y$ is a stand attribute such as height, diameter, density, volume, and the other variables are as defined earlier.

\section{Results}

The estimated parameters of the above model for the various stand attributes for the seven species included in Plonski's
(1974) tables were summarized (Table 1). As expected, the models fitted the tabular (i.e. smoothed) data well with a few exceptions the $R^{2}$ values were larger than 0.98 . As examples of how these equations can be used to prepare variable stocking yield tables, the solution of the fitted equations for black spruce with basal area indices of 20 and $30 \mathrm{~m}^{2} \mathrm{ha}^{-1}$ are provided (Tables 2 and 3). Similar tables for other BI's and/or other species of interest may be generated via the estimated parameters (Table 1).

\section{Application}

Application of the yield functions (Table 1) to single species, even-aged and nearly fully stocked stands should be straight forward as demonstrated (Tables 2 and 3 ) for black spruce. In the case of uneven-aged, multi-species stands such as the boreal mixedwood, an estimate of stand total basal area is needed, preferably via point sampling (or prism count) and an approximate stand age for the main cover type (e.g. black spruce, jack pine, aspen, (poplar), or tolerant hardwood). Equation (1) and its estimated coefficients (Table 1) can then be used to calculate the basal area index of the stand (for the main cover type) via numerical methods (Wang and Payandeh 1993). If two or more species are equally represented in the stand, separate BI's/species component should be calculated and summed to obtain BI for the stand. Having the basal area index of the stand estimated in this way, one may solve the remaining equations for the species/cover-type of interest, similar to Table 2 and 3. Note that accurate age determination in truly uneven-aged stands will be problematic; however, this is true whether it is required for site index or basal area index applications. 
Table 4. Summary of fit statistics for Models (2) and (3) for merchantable basal area and volume for the James River/Marathon data set representing boreal mixedwood in northcentral Ontario

\begin{tabular}{lcccc}
\hline Stand attribute & Model & $\boldsymbol{R}^{\mathbf{2}}$ & RMSE & \% reduction in RMSE \\
\hline Merchantable & {$[3]$} & 0.53 & 9.77 & - \\
Basal area $\left(\mathrm{m}^{2} \mathrm{ha}^{-1}\right)$ & {$[2]$} & 0.70 & 7.82 & 25 \\
Merchantable & {$[3]$} & 0.67 & 73.60 & - \\
Volume $\left(\mathrm{m}^{3} \mathrm{ha}^{-1}\right)$ & {$[2]$} & 0.77 & 61.36 & 20 \\
\hline
\end{tabular}

To evaluate the relative accuracy of basal area index and site index in predicting merchantable volume and basal area at various ages we applied regressions based on both to data from the boreal mixedwood. Data on 197 permanent sample plots, mostly $1 / 10$ acre $(0.04 \mathrm{ha})$ in size, were provided by James River/Marathon Company from the Pic River area in northcentral Ontario. The data consisted of cover type, initial stand age, number of trees, species, and diameter of all trees $>1.5 \mathrm{~cm} \mathrm{DBH}$. The following site-index driven model was used for estimating yield:

$$
Y=b_{1} S I^{b_{2}}\left(1-e^{-b_{3} t}\right)^{b_{4}}
$$

where $S I$ is an approximate site index (dominant height at base age of 50 years) for the main cover type, and other symbols are as defined earlier.

The results indicating that model (2) fit the data much better than model (3) for estimating both merchantable basal area and volume (Table 4). This is perhaps due to the fact that $\mathrm{BI}$ is based on all trees in the stand contributing to the stand basal area and volume while $S I$ is based on a few dominant and codominant heights in the main cover type.

The basal area indices introduced here will provide a measure of realized site productivity for major timber species in Ontario, particularly suitable for the boreal mixedwood cover types, i.e., uneven-aged mixed species stands. Basal area index compares favourably with site index because: (1) it is based on all trees in the stand rather than only a few site trees and therefore it is correlated with the main stand attributes such as density and volume equally or better than site index, (2) it is applicable to mixedwood and uneven-aged stands, where site index does not really apply, and (3) it can be determined easily and inexpensively via horizontal point sampling or prism cruising. Additional comparison of the two indices will be required prior to developing basal area index and variable stocking yield tables for other species and regions. If such comparisons prove the definite superiority of basal area index over that of site index, development of a new family of growth and yield models and tables based on basal area index will be in order. In addition to boreal mixedwood, such yield tables will also be valuable for disturbed hardwood stands in southern Ontario and those in the eastern United States.

\section{Acknowledgments}

The authors thank Canadian Forestry Service for providing financial support for this study under the Science and Technology Program.

\section{References}

Ek, A.R. 1971. A formula for white spruce site index curves. Univ. of Wisconsin, Dept. of For., Madison, WI. Note 161.
Ffolliott, P.F. and D.P. Worley. 1973. Forest stocking equations: their development and application. USDA For. Serv. Rocky Mountain For. and Range Exp. Stn. Res. Pap. RM 102, 8p.

Griegal, D. F. 1984. Shortcomings of soil surveys for forest management. pp. 148-166 In: J.-G. Bockheim (ed.) Proc. Symp. on Forest Land Classification. Experiences, problems, perspectives. USDA For. Serv., North Central For. Exp. Stn., St. Paul, MN. Rep. NCR-102, 209 pp.

Johnstone, W.D. 1976. Variable density yield tables for natural stand of lodgepole pine in Alberta. Dep. of Fish. and Environ., Can. For. Serv., For. Tech. Rep. 20, Ottawa, ON. 110 p.

Lundgren, A.L. and W.A. Dolid. 1970. Biological growth functions describe published site index curves for lake States timber species. USDA For. Ser. Res. Pap. NC-36.

Monserud, R.A. 1984a. Problems with site index: An opinionated review. pp 167-180 In: J.G. Bockheim (ed.) Proc. Symp. on Forest Land Classification. Experiences, Problems, Perspectives. USDA For. Serv., North Central For. Exp. Stn., St. Paul, MN. Rep. NCR-102 209 p.

Monserud, R.A. 1984b. Height growth and site index curves for inland Douglas-fir based on stem analysis and forest habitat types. For. Sci. 30: 943-965.

Payandeh, B. 1973. Plonski's yield tables formulated. Dep. Environ., Can. For. Serv., Ottawa, ON. Publ. No. 1318. 14 p.

Payandeh, B. 1977. Metric site index formulae for major Canadian timber species. Can. For. Serv. Bi-mon. Res. Notes 33(5): 37-39.

Payandeh, B. 1991. Plonski's (metric) yield tables formulated. For. Chron. 67: 545-546.

Pienaar, L.V. and K.J. Turnbull. 1973. The Chapman-Richards generalization of Von Bartalanffy growth model for basal area growth and yield in even-aged stands. For. Sci. 19: 2-22.

Plonski, W.L. 1956. Normal yield tables for black spruce, jack pine, aspen, and white birch in northern Ontario. Ont. Dep. Lands For., Timber Manage. Dir. No. 24, 40 p.

Plonski, W.L. 1960. Normal yield tables pine, aspen, white birch, tolerant Toronto, for black hardwood, Ont. Rep. spruce, jack white pine, and red pine for Ontario. Ont. Dep. Lands For., Toronto, ON. Silvic. Ser. Bull. 2, 39 p.

Plonski, W.L. 1974. Normal yield tables (metric) for major forest species of Ontario. Ont. Min. Nat. Resour., Toronto, ON. 40 p.

Richards, F.J. 1959. A flexible growth function for empirical use. J. Exp. Bot. 10: 290-300.

Turnbull, K.J. and L.V. Pienaar 1966. A non-linear mathematical model for analysis and prediction of growth in non-normal and thinned forest stands. Proc. Sec. Conf. Int. Adv. Group For. Statisticians, Stockholm. p. 319-333.

Wang, Y. and B. Payandeh. 1993. A numerical method for the solution of base-age specific site index model. Can. J. For. Res. 23: 2487-2489.

Yang, R.C., A. Kozak and J.H.G. Smith. 1978. The potential of Weibull-type functions as flexible growth curves. Can. J. For. Res. 8: 424-431. 